\title{
A INSTITUCIONALIZAÇÃO DA DISCIPLINA: o "primitivo" como objeto da ciência
}

\section{THE INSTITUTIONALIZATION OF DISCIPLINE:} the "primitive" as an object of science

Alícia Ferreira Gonçalves*

\section{Resumo}

O presente ensaio discorre sobre a emergência da antropologia como um campo específico do saber institucionalizado na Europa e Estados Unidos, denominada como a Ciência do Homem. O fio condutor do artigo é o processo de institucionalização da disciplina que institui, inicialmente, os povos colonizados, povos ditos primitivos ou arcaicos como objeto da ciência. A antropologia se constitui no final do século XIX como uma disciplina acadêmica que começa a ser ensinada nas universidades dos três centros difusores, a saber, Inglaterra, Estados Unidos e França. O espectro temporal abrange o final do século XIX e as primeiras três décadas do século XX.

Palavras-chaves: Antropologia; Institucionalização; Ciência; Povos Primitivos.

\begin{abstract}
This essay discusses the emergence of Anthropology as a specific field of institutionalized knowledge in Europe and the United States, called the Science of Man. The guiding thread of the article is the process of institutionalizing the discipline that initially instituted colonized peoples, so-called primitive or archaic peoples as the object of science. Anthropology was constituted at the end of the 19th century as an academic discipline that began to be taught at universities in the three diffusion centers, namely, England, the United States and France. The temporal spectrum covers the end of the 19th century and the first three decades of the 20th century.
\end{abstract}

Keywords: Anthropology; Institutionalization; Science; Primitive Peoples.

\section{Prolegômenos}

Como datar a gênese da antropologia? Como estabelecer um marco de origem? Segundo James Clifford (CLIFFORD, 2002), as histórias da antropologia são fascinantes.

\footnotetext{
* Doutora em ciências sociais pela UNICAMP/Brasil. Professora associada do Departamento de Ciências Sociais da UFPB/Brasil, vice-coordenadora do PPGA/UFPB/Brasil. E-mail: aliciafg1@gmail.com.
} 
Onde elas começam? Com Platão? Com o iluminismo? Com o trabalho de campo? Para Lowie (1947), começa com alguns viajantes. Para Lévi-Strauss (1989), a disciplina tem a sua gênese no ano de 1754 com O Discurso sobre as origens da desigualdade entre os homens de Jean-Jacques Rousseau, texto que pode ser considerado o primeiro tratado de etnologia na literatura francesa, porque coloca o problema central da antropologia que é a passagem da natureza para a cultura. Se para Bartolomé de Las Casas (LAS CASAS, 1992), a unidade do gênero humano residia na existência da alma em todos os seres viventes inclusive nos indígenas, ${ }^{1}$ para os antropólogos evolucionistas, a unidade do gênero humano poderia ser comprovada pela suposta existência de certos germes elementares do pensamento, que estariam presentes no homem selvagem, no bárbaro e no homem civilizado. A grande inovação europeia do século XVIII, segundo Helène Clastres (CLASTRES, 1983), no seu belíssimo texto: "Primitivismo e ciência do homem no século XVIII", é pensar os povos selvagens — os habitantes do "novo mundo" como povos primitivos. Primitivos, isto é, primeiros: no começo da história, isto é, de uma história universal que é a do gênero humano. Tem-se a ideia da humanidade como espécie, portanto dotada de uma unidade natural e tendente por natureza à mesma evolução. É no seio das teorias naturalistas que o discurso antropológico dos séculos XVIII e XIX vão se inspirar. Desse modo, tal como o universo, o Homem é cognoscível através de leis, e sendo assim, pode e deve ser objeto de ciência. Como já anunciava James Frazer, para quem a história da humanidade seria uma parte essencial da história da natureza: "nossos pensamentos, desejos e ações funcionam de acordo com leis tão definidas quanto aquelas que governam o movimento das ondas, a combinação de ácidos e alcalinos e o crescimento das plantas e animais" (FRAZER apud CASTRO, 2005, p. 70). A primeira cadeira de antropologia social foi ocupada por Sir James Frazer (18541941) na Universidade de Liverpool em 1908 na primeira década do século XX. Foi a primeira cadeira a ser criada com esse título em uma universidade em todo o mundo. Desse modo, o marco inaugural da disciplina pode ser identificado na palestra proferida por James Frazer, intitulada O escopo da antropologia social, em 14 de maio de 1908. James Frazer, em sua palestra, define a disciplina como antropologia social e recorta o

\footnotetext{
${ }^{1}$ Sobre o tema da existência de alma nos indígenas, portanto passíveis de serem convertidos à fé cristã, e os debates subsequentes consultar Freitas Neto (2003).
} 
seu campo (estudo das sociedades ditas primitivas) delimitando as suas fronteiras e diferenciando-a da sociologia, cujo objeto de estudo seria a sociedade humana na forma capitalista. O presente ensaio foi redigido e direcionado ao público iniciante nas ciências sociais e de outras áreas de graduação, introduzindo a antropologia de forma didática e clara, articulando autores, obras e conceitos norteadores, a partir de uma visão crítica da disciplina.

\section{Evolução: o conceito norteador}

O conceito norteador empregado pelos antropólogos nos primórdios da disciplina é o de evolução, fortemente inspirado não em Charles Darwin, mas sim, em Herbert Spencer, cuja obra de referência é Estatística social de 1851, na qual aparece o termo evolução, que seria extrapolado para pensar o processo evolucionário para todo o cosmo no texto de 1857: Progresso: sua lei e sua causa (SPENCER, 1996).

O conceito de evolução engloba a ideia de uma transformação do mais simples em direção ao mais complexo, envolvendo um processo de sucessivas diferenciações. Tal movimento poderia ser percebido na natureza, nas mudanças do universo (evolução geológica e climática da Terra) e no universo social. "As ideias filosóficas de Spencer levavam à disposição de todas as sociedades conhecidas segundo uma única escala evolutiva ascendente, através de vários estágios. Essa se tornaria a ideia fundamental do período clássico do evolucionismo na antropologia" (CASTRO, 2005, p. 26). Segundo o autor, a disciplina teria como objetivo central identificar as leis gerais e as regularidades subjacentes à evolução da humanidade que ocorreria por estágios sucessivos, do mais simples em direção ao mais complexo, da selvageria em direção ao estágio civilizado. Essa busca por leis e regularidades subjacentes à evolução da humanidade foi o foco central dos autores evolucionistas, que aplicaram em seus estudos o método comparativo a partir de uma perspectiva diacrônica e indutiva, que ia dos aspectos particulares para os mais gerais, não fizeram pesquisa de campo sistemática. Seus dados estavam baseados nas informações coletadas dos viajantes, missionários, administradores coloniais e naturalistas espalhados pelo mundo. James Frazer estudou a evolução do pensamento mágico em direção ao pensamento científico no Ramo de ouro, publicado em 1890. Morgan estudou a evolução das invenções, das descobertas e das instituições (parentesco) 
na sociedade antiga, e Tylor estudou a evolução da sociedade a partir do conceito de cultura concebida como sinônimo de civilização e progresso (TYLOR, 1975).

Para Frazer, a problemática do funcionamento da mente selvagem era o eixo central de sua análise realizada no Ramo de ouro. A intenção do autor é analisar como o pensamento mágico evolui em direção ao pensamento científico através da história, e como o pensamento tido como primitivo, por meio da magia, buscava controlar e regular o mundo. Para explorar a temática do funcionamento da mente selvagem, o referente empírico selecionado foi a regra de sucessão do sacerdócio em Nemi. Aplicando o método comparativo, Frazer buscou pelos equivalentes universais da sucessão. O autor visa demonstrar a existência de regras semelhantes em todo o mundo e através da história; procedendo assim, ele almejou uma explicação universal sobre o funcionamento da mente primitiva. A comparação foi realizada pelo autor a partir de dados retirados de textos bíblicos, das narrativas documentadas nas literaturas de viagens e dos textos etnográficos.

\section{EUA: Associação Americana para o progresso da ciência} 1877 - A sociedade antiga

Lewis Henry Morgan nasceu nos Estados Unidos em 1818, estudou direito formando-se em 1842. Estudou os iroqueses, tribo indígena que habitava o território norte-americano, travando intensos contatos com eles e sendo inclusive adotado pelos nativos como guerreiro seneca do clã do falcão, tornando-se o maior especialista em assuntos iroqueses. O autor estudou as instituições indígenas, principalmente o parentesco que a partir de então se converteu em uma temática clássica da disciplina, tanto é que Claude Lévi-Strauss dedicou o seu livro, As estruturas elementares do parentesco, à memória de Morgan.

Em seu livro, A sociedade antiga (1877), estudou a evolução da humanidade, os estágios do progresso da sociedade humana. O autor analisou cinco sociedades: os aborígenes australianos, os índios iroqueses, os astecas, os gregos e os romanos. Considerando os aborígenes australianos os mais primitivos em seu estágio evolutivo, enquanto o grande marco inaugural do estágio civilizado seria, em sua visão, a origem da propriedade, ou melhor, o desenvolvimento da ideia de propriedade. 
A noção de uma origem comum, de um desenvolvimento unilinear em direção à civilização e de que, portanto os selvagens, os povos primitivos representariam os antepassados do homem civilizado, está presente nas formulações teóricas desse autor:

Como a humanidade foi uma só em sua origem, sua trajetória tem sido essencialmente uma, seguindo por canais diferentes, mas uniformes, em todos os continentes, e muito semelhantes em todas as tribos e nações da humanidade que se encontram no mesmo status de desenvolvimento. Segue-se daí que a história e a experiência das tribos indígenas americanas representam, mais ou menos aproximadamente, a história e a experiência de nossos próprios ancestrais remotos, quando em condições correspondentes (MORGAN apud CASTRO, 2005, p. 46).

Morgan estudou a gênese da ideia de governo a partir da organização em gentes, fratrias e tribos até o estabelecimento da sociedade política. Sobre o conceito de propriedade privada, que marca o estágio civilizado, o autor nos diz,

A ideia de propriedade foi lentamente formada na mente humana, permanecendo em estado nascente e precário por imensos períodos de tempo. Surgindo durante a selvageria, requereu toda a experiência daquele período e da subsequente barbárie para desenvolver-se e preparar o cérebro humano para a aceitação de sua influência controladora. Sua dominância, como uma paixão acima de todas as outras, marca o começo da civilização (MORGAN apud CASTRO, 2005, p. 47).

O desenvolvimento dessas instituições é demonstrado pelo autor a partir de um recurso analítico de um quadro classificatório denominado de períodos étnicos: selvageria (inicial, intermediário e final), barbárie e civilização. ${ }^{2}$

Tylor (nascido em 1832 na Inglaterra) estudou a evolução das sociedades tendo como eixo central o conceito de cultura. Sua obra de referência é Cultura primitiva: pesquisas sobre o desenvolvimento da mitologia, filosofia, religião, linguagem, arte e costume publicado em 1871. Sem formação acadêmica, atuou institucionalmente na

\footnotetext{
${ }^{2}$ A obra de Morgan ganhou uma significação na época tendo influenciado as formulações teóricas de Marx e Engels. Karl Marx leu o livro entre 1880 e 1881, tomando 98 páginas de anotações. E Engels utilizouse amplamente de tais notas para escrever $A$ origem da família, da propriedade privada e do Estado. Castro nos informa que a obra de Morgan se tornou doutrina antropológica oficial da União Soviética. Sua atuação institucional foi na Associação Americana para o Progresso da Ciência onde institucionalizou uma subseção permanente de antropologia na Academia Nacional de Ciências. Após as suas publicações, foi considerado, na época, o maior especialista em antropologia nos EUA, sendo procurado por jovens que queriam seguir carreira na área (CASTRO, 2005).
} 
Sociedade Britânica para o Progresso da Ciência, onde publicou uma espécie de guia para viajantes e profissionais que iriam residir em países "não civilizados", que seguia em linhas gerais as ideias desenvolvidas na obra Cultura primitiva. Em 1881, publicou uma espécie de manual sobre a disciplina que teria ampla divulgação no país: Antropologia: uma introdução ao estudo do homem e da civilização. Em 1883, foi nomeado conservador do museu da Universidade de Oxford; na época, era reconhecido como a maior autoridade em antropologia na Inglaterra, e no ano seguinte, foi eleito presidente da Seção Antropológica da Sociedade Britânica para o Progresso da Ciência. Em 1884, tornou-se o primeiro leitor (reader) de antropologia de Oxford e Grã Bretanha; em 1896, recebeu o grau mais elevado da vida acadêmica britânica: professor titular. Aposentou-se como professor emérito em 1906. Com a condecoração de Cavaleiro da Coroa Britânica, recebeu o título de Sir.

Cultura, na concepção de Tylor, era tida como sinônimo de civilização, aquele todo complexo que inclui artes, religião, tecnologia, costume e quaisquer outras capacidades e hábitos adquiridos pelo homem na condição de membro da sociedade. Civilização é representada, nessas formulações, como uma conquista progressiva, cumulativa e distintamente humana. Os seres humanos são semelhantes, pelo menos em potencial. Todos são capazes de criar uma civilização, o que depende do dom exclusivamente da razão como principal atributo que particulariza a espécie humana e que a distingue de outros animais. Cultura, nesse contexto, aparece em sua acepção universalista e etnocêntrica em contraposição às concepções posteriores que incorporam uma perspectiva relativista e particularista, a exemplo de Franz Boas, que já no início do século $\mathrm{XX}$, a partir da noção de kultur, formulou um conceito de cultura como configurado por um complexo de traços que refletem, em última instância, o espírito (Geist) de uma nação. ${ }^{3}$

Como dito anteriormente, na era evolucionista da disciplina, o objetivo era a reconstituição da história das origens e dos estágios de evolução da humanidade definidos a partir de uma perspectiva evolucionista e unilinear em: selvageria, barbárie e civilização. Essa concepção teleológica da história (que caminha necessariamente para

\footnotetext{
${ }^{3}$ Sobre o conceito de cultura na antropologia, consultar Gonçalves (2010).
} 
uma finalidade determinada) está baseada no pressuposto da existência empírica de certos germes originais, elementares do pensamento. No entanto, tais germes elementares se desenvolveriam de forma desigual, em ritmos distintos; o desenvolvimento desigual, segundo a teoria, explicaria as diferenças entre os homens situando-os em estágios diferentes. Em função desses germes elementares, a humanidade se desenvolveria em uma única direção ao progresso e à civilização, cujo modelo seria a Inglaterra Vitoriana do século XIX. A ideia que começava a se consolidar, ao menos na Europa, é a de que existiria uma lógica subjacente ao funcionamento do universo que remete ao plano da natureza, a mesma lógica seria aplicada à análise do funcionamento do universo social. Esse pressuposto teórico foi incorporado de uma forma muito sutil nas formulações de Durkheim e Lévi-Strauss, afinal a estrutura inconsciente e universal de que nos fala o mestre francês teria origem no espírito humano no estágio do pensamento inconsciente que também remete ao plano cósmico (LÉVI-STRAUSS, 1989). Nesse sentido, o projeto epistemológico dos primeiros antropólogos vinculados à escola evolucionista era transformar a disciplina em uma ciência do homem, e como tal, justificou no plano científico da época a empreitada colonizadora denunciada por diversos autores tais como, Copans e colaboradores (1971), Kuper (1988), Lecrerc (1978), Mercier (1986), Lowie (1947), dentre outros. Denominada por Stocking Jr. (1993) como uma ciência colonial.

Em contraposição à noção de evolução, coexistia a noção de difusão e de traços culturais, estamos falando das teorias difusionistas na Inglaterra e Alemanha.

\section{Difusionismo: a teoria dos círculos culturais}

Os difusionistas deram o nome de etnologia à disciplina que incluía o estudo comparativo e a classificação dos povos, baseados na cultura material, linguagem, instituições, ideias religiosas e sociais em contraste com os caracteres físicos. Havia uma ênfase na influência da geografia na cultura. A cultura era formada por um complexo de traços originados em um ponto inicial, e a partir desse ponto, se difundiria para outros espaços geográficos. Nesse sentido, ela era composta por um complexo de traços culturais. A teoria pode ser aplicada para qualquer aspecto da cultura entendida em sentido amplo: tecnologia, artes, linguagem, rituais, costumes, dentre outros. A teoria difusionista foi amplamente difundida na Grã-Bretanha justamente em um momento 
histórico em que as descobertas arqueológicas sobre o Egito afirmavam que o "fértil crescente" era o berço da civilização, propagada por Elliot Smith e Perry na década de 1920 no University College de Londres. Para eles, havia apenas um centro de difusão de inovação, difusão heliocêntrica que era o Egito antigo do qual todos os traços culturais eram difundidos. Nesse sentido, as pirâmides pré-colombianas poderiam ser consideradas fruto de um empréstimo cultural, elas seriam uma transcrição das pirâmides egípcias. $\mathrm{Na}$ Alemanha e Áustria, os principais expoentes dessa corrente foram o padre Wilhem Schmidt e Fritz Graebner vinculados à Escola de Viena, que desenvolveram a teoria dos círculos culturais. Segundo essa teoria, os traços culturais difundiam-se em círculos para outras regiões por meio de centros culturais variados. O conceito de difusão auxilia a explicar por que que alguns traços culturais são adquiridos por empréstimos ou espalhados em espaços geográficos variados, nesse sentido, nos permite explicar a aculturação. A ideia de empréstimo e de traços culturais foi incorporada na antropologia norte-americana via Franz Boas, contudo, a partir de uma abordagem crítica, o autor rejeitou o determinismo geográfico e o determinismo biológico.

\section{Culturalismo norte-americano: relativismo cultural (1896)}

As teorias evolucionistas do século XIX começaram a ser questionadas por antropólogos da geração seguinte nos Estados Unidos com Franz Boas, na França com Émile Durkheim e Marcel Mauss, e na Inglaterra com B. Malinowski e R. Brown. Em oposição à noção de evolução, os autores citados, a partir de abordagens próprias (funcionalista, estruturalista e culturalista), defendiam a abordagem relativista que dizia que os costumes e as instituições "nativas" deveriam ser contextualizados e estudados nos termos de suas respectivas culturas. Havia o pressuposto de que cada cultura formava uma totalidade orgânica, coesa, integrada, autônoma do universo exterior e encerrada em si mesma e que cada cultura era particular, possuía, portanto, idiossincrasias. Essas escolas tinham em comum um projeto ambicioso de transformar a antropologia em uma ciência similar às ciências naturais. Nesse sentido, como afirma Roberto Cardoso de Oliveira (OLIVEIRA, 1988), o ideal de cientificidade sempre esteve presente no 
horizonte da disciplina no período de sua institucionalização, ideal que viria a ser questionado a partir do paradigma hermenêutico no final do século XX.

O marco de origem do culturalismo norte-americano pode ser identificado com a publicação de um artigo de Franz Boas em 1896: As limitações do método comparativo em antropologia social, publicado no livro Raça, linguagem e cultura. Nesse mesmo ano, ingressa na universidade de Columbia lecionando inicialmente antropologia física. Até então, a disciplina era mais conhecida como etnologia, o que incluía também a antropologia física. Boas, partindo de uma crítica contundente ao método comparativo utilizado pelos antropólogos evolucionistas, propõe um redirecionamento da disciplina, particularmente de seus objetivos e do seu método. Em contraposição ao estudo da história da evolução cultural da humanidade, o autor propõe o estudo de culturas particulares que estão contextualizadas em um tempo-espaço determinado, aquele do observador, do antropólogo. Em contraposição ao método comparativo, o autor propõe o método histórico, indutivo e empirista que permite ao antropólogo a observação direta dos povos estudados. Boas nos EUA, e Malinowski na Inglaterra, sistematizaram e instituíram os princípios básicos do trabalho de campo.

O ponto central da crítica boasiana é dirigido ao método comparativo utilizado nos estudos evolucionistas: o isolamento de uma mesma classe de fenômenos descontextualizados, por exemplo, sistemas de parentesco observados em várias sociedades no tempo e no espaço e a sua comparação e classificação em estágios evolutivos desvinculados de seus respectivos contextos socioculturais. Partindo da crítica dirigida ao método comparativo, e a partir de estudos realizados em várias sociedades, notadamente as do noroeste americano, o autor desconstrói o argumento evolucionista (das noções de uma origem comum e dos estágios de evolução). Para o autor, não existem leis universais que regem o funcionamento da mente humana e que explicaria a origem das formas de organização social, dos sistemas religiosos ou dos sistemas de parentesco. Tampouco, a evolução poderia ser explicada em termos unilineares. As similaridades culturais não poderiam ser explicadas em função de uma suposta unidade do gênero humano, particularmente em função de certos germes elementares que regulariam o funcionamento da mente humana, uma vez que a mente humana reagia de forma semelhante quando confrontada com as circunstâncias ambientais familiares. Boas 
explicou as similaridades culturais em função de fatores históricos, ambientais e culturais, principalmente a partir da noção de contato cultural e de empréstimo.

Ele passou a defender uma visão "histórica" particular da cultura. As culturas são formadas por traços e complexos de traços que são o produto de condições ambientais, fatores psicológicos e conexões históricas. Baseou-se em seus estudos da distribuição espacial dos mitos, das lendas e do folclore. Os elementos de qualquer cultura eram produtos de processos históricos complexos envolvendo, em larga medida, a difusão e o empréstimo de traços e complexos de traços de culturas vizinhas. Incorporando a perspectiva histórica nos estudos antropológicos, propõe uma reformulação dos objetivos da disciplina. Segundo o autor, o objetivo da investigação antropológica seria descobrir os processos por meio dos quais certos aspectos da cultura se desenvolveram, ou seja, investigar as razões de existência de determinados costumes, das crenças, da forma de organização social, dos sistemas religiosos, a partir da história do seu desenvolvimento. Para atingir esse objetivo, Boas propõe o estudo de cada cultura apreendida em sua autonomia, particularidade e em sua totalidade, que envolve, para o autor, considerar na análise antropológica a inter-relação entre os vários aspectos que compõem uma cultura. Por exemplo, o estudo de um costume deve ser realizado em relação com os outros aspectos que compõe uma cultura, a fim de se apreender as inter-relações que existem entre os seus vários aspectos, é nesse sentido que uma cultura dever ser apreendida em sua totalidade. Deve ser considerada na análise, a distribuição geográfica da mesma classe de fenômenos, o objetivo é investigar as causas históricas que levam ao desenvolvimento de uma mesma classe de fenômenos e o processo psicológico que influencia no desenvolvimento do costume em estudo. A integração de elementos em conjuntos culturais é uma integração psicológica fundada em ideias e não em condições externas envolvendo a combinação entre processos conscientes e inconscientes, nas relações entre indivíduo e sociedade. Inspirado na noção de Geist, oriunda do idealismo alemão, Boas estudou o modo como o gênio de um povo no nível inconsciente integrava os elementos de uma cultura. Embora as categorias subjacentes e as ideias dominantes da cultura de um povo fossem em última instancia produtos históricos, existiriam a priori, no sentido de que se desenvolvem no presente em cada indivíduo, e em todo o povo de forma inconsciente. "Em última análise, era nesse nível inconsciente que os elementos culturais 
tinham a sua integração no gênio de um povo" (STOCKING JR, 2004, p. 28). A integração dos elementos não era uma integração lógica e sistêmica, o era, em termos de significado, tema, foco e padrão. Boas incorporou à antropologia norte-americana o estudo da vida mental dos povos primitivos, o aspecto subjetivo do indivíduo (como um ser dotado de uma interioridade mental). Publicou, em 1911, o livro A mentalidade do homem primitivo que é uma coletânea de vários textos produzidos de 1894 a 1911.

Havia em suas formulações teóricas uma tensão entre as ciências da natureza e as ciências do espírito, que de certa forma era um reflexo da sua formação inicial de físico. Em seu texto de 1904, no qual discorre sobre a história da antropologia, afirmava que ela era em parte um ramo das ciências biológicas e um ramo das ciências da mente. Entre os fenômenos mentais estavam a linguagem, a invenção, a arte, a religião, a organização social e as leis. Parecia resolver essa tensão recorrendo ao método histórico que visava em última instância identificar leis gerais e científicas subjacente ao desenvolvimento de determinado costume ou instituição. Tais leis existiam na natureza e eram externas à mente do observador, para tanto propôs o método indutivo:

\footnotetext{
Pesquisar a história completa do fenômeno particular servia a um duplo objetivo: por um lado, removia a influência dos ambientes, de modo que se podia chegar à subestrutura fisiológica e psicológica do homem; por outro, uma vez que os fenômenos que surgem de uma causa física comum a todas as tribos podiam ser assim isolados, uma comparação das histórias dos desenvolvimentos poderia levar às descobertas de leis gerais do desenvolvimento humano (STOCKING JR, 2004, p. 28-29).
}

A segunda questão discutida na antropologia boasiana, e depois reproduzida na geração seguinte de antropólogos, principalmente com Kroeber e os autores vinculados à escola de cultura e personalidade, eram as relações entre raça e cultura, natureza e cultura. O tema da unidade psíquica da humanidade é retomada e interpretada pela escola boasiana em termos biológicos; se para os evolucionistas existe uma unidade psíquica universal e atemporal fundamentada em certos germes elementares do pensamento, para Boas, havia uma unidade psíquica da humanidade no plano biológico, da natureza, (em oposição ao plano da cultura) que determina as necessidades psíquicas, que seriam solucionadas culturalmente; a cultura, e não a raça, explica a variabilidade. Raça é diferente de cultura. O tema da unidade psíquica foi retomado pela escola sociológica francesa. Para Boas, os 
comportamentos individuais são moldados de acordo com a cultura. Nesse sentido, os hábitos sociais de um determinado grupo social refletem os traços culturais que formam uma determinada cultura. Para ele, a cultura exerce uma coerção, determina o comportamento individual. Esta ênfase no papel da cultura sobre a conduta individual e social vai estar presente nas formulações teóricas das gerações seguintes de antropólogos desde Kroeber até Margareth Mead e Ruth Benedict. O conceito de cultura veio a ser reformulado na antropologia norte-americana no final da década de 1970 e início da década de 1980, com a publicação do livro a Interpretação das culturas, no qual Clifford Geertz propõe uma redefinição do conceito de cultura a partir de uma abordagem semiótica (GEERTZ, 2008).

\section{Escola sociológica francesa: as categorias do entendimento} 1895

Se a gênese do culturalismo norte-americano pode ser datada (como mencionamos anteriormente) no ano de 1896, podemos considerar 1895 o ano da primeira publicação das Regras do método sociológico de Durkheim, o marco inicial da escola sociológica francesa, que em sua primeira fase estava articulada ao grupo de intelectuais filiados à publicação de L'anée Sociologique sob a direção de Durkheim. Émile Durkheim (18581917) e seu sobrinho Marcel Mauss (1872-1950) foram os intelectuais responsáveis pelo processo de institucionalização da disciplina na França na fase inicial, quando ainda não existia uma disciplina autônoma da sociologia com o nome de antropologia.

Nas regras do método sociológico, Durkheim formula os princípios básicos metodológicos da disciplina Sociologia. Ele delimita seu campo de estudos, seu objeto e o seu método em relação à história, à filosofia e à psicologia. A finalidade central do autor é fundar um discurso científico que toma como objeto a sociedade, especificamente o fato social, independentemente das outras disciplinas citadas. Desse modo, os fatos sociais não deveriam ser explicados pela psicologia e sim a partir de outros fatos sociais. $\mathrm{O}$ segundo preceito era tratar os fatos sociais como coisas exteriores ao sujeito do conhecimento, procedimento análogo ao das ciências naturais. Marcel Mauss atuou 
diretamente em parceria com Durkheim, e após a sua morte em 1917, continuou o projeto do tio até 1940, ano de sua jubilação no Collège de France. ${ }^{4}$

Iniciou muito cedo suas atividades docentes, aos 23 anos, inicialmente no campo da filosofia, e depois dedicou-se ao estudo das religiões primitivas e orientais. Publicou em parceria com Hubert, em 1898, o Ensaio sobre o sacrifício. ${ }^{5}$ Segundo o autor, a oposição entre sociedades primitivas e civilizadas era falsa porque, o que de fato existiriam, eram sociedades com civilizações diferentes onde se poderia apreender sociologicamente a unidade do gênero humano. Relativizou a noção de objetividade proposta por Durkheim e ampliou a noção de fato social. A noção central formulada por Mauss é a de fato social total ou fenômeno social total que ele apresentou no Ensaio sobre a dádiva em 1925 (MAUSS, 1974). Partilhava também de uma concepção sistêmica de sociedade, concebida como uma totalidade integrada, orgânica e coesa, que se expressaria empiricamente nas instituições sociais, a exemplo do Kula, que integraria simultaneamente todas as dimensões da sociedade: política, jurídica, religiosa, econômica, moral e psicanalítica. Defendia a articulação no nível metodológico entre a sociedade e o indivíduo. Na visão dos autores, as sociedades mais simples, ${ }^{6}$ menos complexas, seriam o lócus privilegiado de observação porque nessas sociedades poderiam se identificar as características mais elementares e essenciais por meio dos quais a religião se define, ou seja, as representações fundamentais, as atitudes rituais e também as relações que se estabelecem entre as coisas.

Como disse Durkheim, "para compreender as religiões mais recentes é preciso buscar na história a maneira pela qual se constituíram progressivamente" (DURKHEIM, 1990, p. 31). Nessa afirmação, está implícita a ideia de evolução - a noção de que nos fenômenos simples estão os elementos essenciais, que vão se complexificando através do tempo, através da história. A sociedade primitiva é concebida como uma totalidade integrada e coesa graças ao papel coercitivo exercido pela consciência coletiva sobre as

\footnotetext{
${ }^{4}$ Formação inicial em filosofia. Em 1901, atua como docente na Escola de Altos Estudos lecionando história das religiões dos povos não civilizados. Em 1917, com a morte de Durkheim, assume o Instituto de Etnologia; em 1930, assume uma cátedra no Collège de France.

5 Publicações: 1898, Ensaio sobre o sacrifício com Hubert; 1901, Grande encyclopédie sobre sociologia com Fauconnet; 1903, Algumas formas primitivas de classificação com Durkheim; 1904, Esquisse d'une theorie générale de la magie; 1925, Ensaio sobre a dádiva.

${ }^{6}$ Essa noção de sociedade primitiva como sociedade simples e que se opõe a uma sociedade complexa, elementar, uma espécie de laboratório, foi criticada no texto de Márcio Goldman (GOLDMAN, 1995).
} 
consciências individuais. Por contraste, nas sociedades industriais, caracterizadas pela divisão do trabalho social em sua forma mais desenvolvida, a coercitividade seria menos expressiva, consequentemente o grau de coesão social seria menor. Émile Durkheim, inicialmente delimita o objeto de estudo da sociologia à sua própria sociedade, como no estudo do suicídio, porém incorpora posteriormente na disciplina o estudo da religião e dos sistemas de classificação das sociedades primitivas, baseado nos materiais recolhidos por outros antropólogos em suas pesquisas de campo, dentre eles W. Baldwin Spencer e F. J. Gillen, que pesquisaram os aborígines australianos e publicaram as suas pesquisas no ano de 1899. Durkheim propõe uma abordagem racionalista dos fatos sociais, no sentido de que o conhecimento da realidade para o sociólogo não passa necessariamente pela observação empírica dos fenômenos e do comportamento humano, mas pela apreensão nas representações coletivas, nas categorias do entendimento que são constituídas socialmente sem que os indivíduos tenham consciência.

As publicações de 1903 e 1913 (Algumas formas primitivas de classificação, escritas com Marcel Mauss, e As formas elementares, respectivamente) marcam o início de uma reorientação na trajetória intelectual de Durkheim, que se orientaria para o estudo das religiões nas sociedades primitivas. ${ }^{7}$ Em parceria com o sobrinho iniciaria uma tradição intelectual na escola francesa direcionada aos estudos das sociedades primitivas a partir de uma abordagem racionalista com foco nas representações coletivas. Nesse sentido, Durkheim defende o argumento de que uma análise sociológica da religião não tem que focar o seu estudo nos símbolos, nas formas aparentes de que ela se reveste, mas nos significados que ela exprime. Nesse sentido, é preciso estudar a origem e a essência da religião. É na esfera dos significados que se apreende a realidade que a religião exprime, a essência que nada mais é que a própria sociedade. É, portanto, nas formas elementares que vamos identificar os elementos permanentes, essenciais dos fatos sociais,

[...] é preciso começar por remontar até a sua forma mais primitiva e mais simples, procurar perceber os caracteres pelos quais ela se define nesse período de sua existência, depois fazer ver como, pouco a pouco, ela se desenvolveu e

\footnotetext{
7 "Foi neste ano quando, pela primeira vez, encontrei a maneira de abordar sociologicamente o estudo da religião. O curso de 1895 supõe uma linha divisória no desenvolvimento de meu pensamento, a ponto que tive de revisar todas as minhas investigações anteriores, para ajustá-las a esta perspectiva" (DURKHEIM, 1989, p.7).
} 
se tornou complexa, como veio a ser o que é no momento considerado (DURKHEIM, 1989, p. 31)

Por exemplo, no estudo das religiões, cabe identificar e explicar as leis subjacentes ao sistema. Segundo o autor, os elementos essenciais, fundamentais, elementares, constitutivos vão estar presentes em todas as religiões. Para isso, o estudo das sociedades primitivas não seria conduzido apenas pela observação empírica, e não é nos relatos nativos que se aprende a estrutura, mas a partir do método utilizado pelo antropólogo, do comparativo e indutivo, do particular para o geral, elaborando leis válidas universalmente, exercício de abstração do antropólogo. A descrição etnográfica vai lhe oferecer matériaprima para a elaboração de leis de validade geral. Sendo o totemismo entre os aborígines australianos a religião mais primitiva, segundo os autores, conteria uma estrutura elementar que serviria de base para o entendimento. O totemismo é um culto de clã; o deus do clã é o próprio clã divinizado pela sociedade. O totemismo é a forma mais elementar, mais primitiva de religião e não é preciso recorrer a qualquer elemento de empréstimo de outras religiões para explicá-lo. Ele está na raiz de um sistema cognitivo aborígine, portanto de um sistema classificatório que ordena os seres e as coisas de acordo com uma lógica binária e contrastiva, cujo modelo é oferecido pela própria organização dos homens na sociedade. $\mathrm{O}$ totemismo simboliza a coesão social, e a sua essência reside no seu caráter dinamogênico que articula e separa as esferas sagrada e profana da existência social.

Tais sistemas classificatórios conferem identidade e agrupam, atribuem oposições e dividem, hierarquizam as coisas, atribuem funções sociais, estabelecem relações entre as coisas da natureza e entre os animais conforme modelo gerado pela sociedade. Para o autor, as coisas estão dispostas em uma ordem lógica, mantendo relações umas com as outras. As representações se estruturam e funcionam como elemento lógico do pensamento. Nas Formas elementares da vida religiosa, o autor sugere a existência de razão universal presente tanto na natureza como na sociedade, uma ordem cósmica que ordena e classifica as coisas e os homens, põe em perspectiva simétrica mundo social e natural:

As relações fundamentais que existem entre as coisas - aquelas justamente que as categorias têm função exprimir - não poderiam, pois, ser 
essencialmente dessemelhantes de acordo com os reinos. Se, por razões que devemos pesquisar, mostram-se de maneira mais evidente no mundo social, é impossível que não se encontrem alhures, ainda que sob formas mais veladas. A sociedade torna-as mais manifestas, mas não tem o monopólio delas. É assim que noções elaboradas sobre o modelo das coisas sociais podem nos ajudar a pensar as coisas sobre a natureza (DURKHEIM, 1989, p. 48, grifos nossos).

\section{Bronislaw Malinowski}

$1922-1938$

Malinowski, polonês naturalizado inglês, realizou a sua formação em ciências exatas: física e matemática e, assim como F. Boas, reorientou a sua carreira para a antropologia quando esteve entre os esquimós na terra de Baffin. Para ele, a leitura do livro O ramo de ouro de James Frazer foi decisivo. Ambos tiveram contato com a antropologia na Alemanha. Boas em Berlim com Bastian, e Malinowski em Leipzig, sob a orientação de Karl Bücher e WilhelmWundt. Franz Boas nos EUA na Universidade de Colúmbia, e Bronislaw Malinowski na Inglaterra, na London School of Economics (LSE), desenvolveram e sistematizaram os princípios fundamentais do trabalho de campo, que a partir de então se tornou a marca distintiva da antropologia nestes dois países por contraste à abordagem racionalista. ${ }^{8}$ Contudo, enquanto Boas recorreu à história como recurso metodológico, Malinowski enfatizou a relevância da observação direta dos fatos por meio da observação participante, da imersão na cultura e da interiorização das categorias nativas a partir da vivência prolongada do etnógrafo junto às populações etnografadas. Nesse sentido, para Malinowski, o trabalho de campo e a prática etnográfica fundamentada não na história, como defendia F. Boas, mas no "presente etnográfico" se constituem como dimensões epistemológicas centrais para a construção das teorias antropológicas a partir do conhecimento e da interiorização das categorias nativas.

A proposta metodológica de Malinowski apresentada no primeiro capítulo de sua monografia mais conhecida, Argonautas do Pacífico Ocidental de 1922, (MALINOWSKI, 1978) está vinculada, e supõe uma teoria, à teoria funcionalista que

\footnotetext{
${ }^{8}$ Antes de1899, W. Spencer e Gillen realizaram trabalho de campo entre os aborígines australianos por ocasião da expedição organizada por Cambridge ao Estreito de Torres. Contudo foram Boas e Malinowski que desenvolveram de modo mais sistemático e conferiram ao trabalho de campo um estatuto epistemológico central na disciplina.
} 
está articulada a uma concepção específica de cultura. Assim como Boas, Malinowski realiza uma crítica às teorias evolucionistas com relação ao método comparativo e à concepção de história, uma história especulativa, e denuncia também as ligações dos antropólogos evolucionistas com a administração colonial inglesa, afinal o evolucionismo teria servido como justificação teórica do colonialismo europeu, particularmente do império britânico. ${ }^{9} \mathrm{O}$ funcionalismo é uma teoria que se contrapõe ao evolucionismo e que dialoga com a antropologia de Boas com relação ao trabalho de campo, e com os conceitos formulados por Durkheim. Segundo Malinowski, a disciplina deveria abandonar o seu projeto inicial que era o estudo das origens e dos estágios de evolução através da história, e se colocar como objetivo a apreensão sincrônica da cultura nativa como uma totalidade integrada, coesa e coerente. A reconstituição da história dos povos primitivos não seria possível pela ausência de registros escritos, por isso rejeita a abordagem diacrônica. Nesse sentido, a totalidade é um suposto teórico e metodológico. Essa integração e coerência da cultura nativa estão articuladas ao conceito de função e à noção de sistema. A totalidade é composta por vários elementos que estão relacionados entre si e que desempenham cada qual uma função na totalidade ou no sistema. É essa integração funcional entre os elementos que permite o funcionamento do sistema. $\mathrm{O}$ fundamental é a (inter) relação entre os elementos do sistema. Para Boas, a integração entre elementos em conjuntos culturais era psicológica combinando processos conscientes e inconscientes inspirado na noção de Geist. Para Malinowski, a integração é sistêmica, há uma integração funcional derivada de uma concepção sistêmica de sociedade, que por sua vez é concebida como um organismo.

Nesse sentido, a cultura teria como função satisfazer as necessidades (primárias, derivadas e integrativas) de natureza biológica por meio de suas instituições, como a família ou a magia. Para os evolucionistas, a unidade do gênero humano residiria em certos germes elementares do pensamento; para Malinowski esta unidade estaria no plano fisiológico. Segundo o autor, as necessidades são universais porque derivam do plano biológico. Cada sociedade, por meio da cultura e de suas instituições, atende a tais necessidades de forma particular. Ele foi acusado de reduzir e simplificar o conceito de cultura - especialmente no livro Uma teoria cientifica da cultura, publicado em 1944

\footnotetext{
${ }^{9}$ Sobre as ligações entre a antropologia e o Império britânico, consultar, George Stocking Jr. (1987).
} 
— remetendo-a às relações de causa e efeito. Foi considerado o etnógrafo por excelência, porém criticado como teórico.

A apreensão da cultura em sua totalidade só é possível, segundo o autor, a partir da vivência prolongada do etnógrafo junto à população a ser etnografada. Malinowski desenvolveu o seu trabalho de campo nas ilhas Trobriand nos anos de 1915 a 1916 e 1917 a 1918. Durante esse período, escreveu sobre a atividade econômica, parentesco, família, vida sexual, mitologia e magia dos trobriandeses. Segundo ele, a totalidade da cultura poderia ser apreendida por meio da análise de um aspecto da cultura. Não a partir do ponto de vista do etnógrafo, e sim das pessoas que vivenciam aquela cultura. Em Argonautas do Pacifico Ocidental, o autor elegeu como unidade de análise o kula, como unidade multidimensional, e a partir desta instituição, ele reconstituiu a totalidade da cultura trobriandesa.

No primeiro capítulo dos Argonautas, ele apresenta os procedimentos metodológicos do trabalho de campo e da etnografia. Separa a etnologia, que se refere às teorias especulativas, da etnografia que seria uma ciência do Homem. Nesse sentido, a etnografia envolve o trabalho de campo que sempre está atrelado a uma abordagem teórica e visa a descrição ou a reconstituição da cultura como totalidade. Cultura apreendida e reconstituída do ponto de vista nativo. A primeira fase do trabalho de campo está relacionada à imersão na cultura nativa, à interiorização das categorias culturais nativas, ao domínio da língua e à observação participante que envolve a participação na vida nativa, essa fase pressupõe o isolamento do etnógrafo. Somente a partir da observação participante e da interiorização das categorias nativas é que se pode apreender os "imponderáveis", uma totalidade integrada que para o nativo é inconsciente. Há uma preocupação com o estatuto científico da etnografia, desse modo, há uma etapa de coleta de dados brutos e outra etapa de interpretação, a interpretação que descobre as leis gerais, que distingue o essencial do irrelevante, que classifica e ordena os fenômenos, relacionando-os mutuamente.

A fase seguinte é a coleta e sistematização dos dados. Dados coletados de informantes e da observação direta. Etnografia como ciência deveria buscar estabelecer leis gerais e identificar as regularidades da vida social. Articulação entre trabalho de campo e teoria, o etnógrafo tem que se inspirar na teoria e estabelecer problemas antes de 
ir a campo. Os pressupostos da teoria funcionalista são: 1) dissonância entre discurso e práticas sociais concretas, nesse sentido, o discurso nativo são racionalizações acerca das práticas sociais e do comportamento nativo; 2) em muitos casos, há a manipulação das regras sociais em função dos interesses individuais. Subjacente à teoria há uma determinada concepção de indivíduo similar ao "Homem econômico" inventado pela ciência econômica liberal do século XIX, que calcula meios e fins e a maximização dos seus resultados. Por isso, a ênfase na observação direta do comportamento concreto. Essa concepção particular de indivíduo que manipula as regras sociais em proveito próprio estará subjacente às formulações teóricas dos autores britânicos, assim como a abordagem empirista que é a característica central dessa escola. Para os autores que estudamos aqui, o "encontro" com o "Outro", ou seja, o exercício da alteridade, leva a um encontro consigo mesmo e a uma autocrítica da sociedade do observador. Segundo Malinowski, o sentido primeiro da investigação etnográfica é apreender o ponto de vista nativo, a "visão de seu mundo", mesmo porque, as pessoas desejam diferentes formas de felicidade.

\section{Considerações finais}

Em meados da década de 1960, com Clifford Geertz no livro $A$ interpretação das culturas, a disciplina entra na sua fase dita pós-moderna questionando os pressupostos cientificistas e positivistas que fundamentaram a sua institucionalização. Geertz redefine o conceito de cultura e lança a proposta de uma antropologia interpretativa, cuja finalidade seria desvendar "as teias de significado". O pós-modernismo é um movimento abrangente e se faz presente em vários campos do conhecimento desde a arquitetura, artes plásticas, fotografia, artes cênicas, no estilismo, música, cinema, literatura, história, geografia e ciências sociais, incluindo a antropologia. De uma forma ampla o pósmodernismo crítica e se opõe às grandes narrativas de caráter totalizante, isto é, as metanarrativas que são as interpretações teóricas de larga escala pretensamente de aplicação universal, como por exemplo, o estruturalismo e o marxismo, à história dos grandes eventos e personagens, à rigidez da ciência e da racionalidade, à fixidez das formas arquitetônicas. Se contrapõe à crença em um progresso linear, na imanência de um telos subjacente a uma história universal e às verdades absolutas. O pós-moderno, em 
contraste, privilegia a heterogeneidade, o pluralismo, a diferença, a fluidez, o hibridismo, a biografia. A crítica pós-moderna à antropologia se refere às três dimensões: 1) epistemológica, focalizada na autoria e na construção do texto etnográfico; 2) política, que se refere aos conceitos de cultura e identidade formulados na tradição clássica para pensar sobre sociedades isoladas e estáticas e são limitadas para pensar realidades mutantes, fluidas e transnacionais, 3) critica a noção de sociedades ditas "primitivas" como uma espécie de laboratório inspirado nas ciências biológicas. Por fim, retornando a Helène Clastres (CLASTRES, 1983) a própria noção de "Homem primitivo", como primeiros, como espécie, sempre fora uma projeção idealizada pelos antropólogos, uma visão idílica.

\section{Referências}

CASTRO, Celso (org.). Evolucionismo cultural. Textos de Morgan, Tylor e Frazer. Rio de Janeiro: Jorge Zahar Editor, 2005.

CLASTRES, Hélène. Primitivismo e ciência do homem. Discurso. São Paulo, n. 13, p. 187-208, 1983. DOI: https://doi.org/10.11606/issn.2318-8863.discurso.1980.37896. Disponível em: https://www.revistas.usp.br/discurso/article/view/37896. Acesso em: 02 nov. 2020.

CLIFFORD, James. A experiência etnográfica: antropologia e literatura no século XX. Rio de Janeiro: Editora da UFRJ, 2002.

COPANS, J. et al. Antropologia ciência das sociedades primitivas? Lisboa: Ed.70, 1971.

DURKHEIM, E. As formas elementares da vida religiosa. São Paulo: Paulinas, 1990.

DURKHEIM, Emile. As formas elementares da vida religiosa. São Paulo: Paulinas, 1989.

FREITAS NETO, José Alves de. Bartolomé de Las Casas: a narrativa trágica, o amor cristão e a memória americana. 2002. Tese (Doutorado em História Social) — Faculdade de FFLCH, Universidade de São Paulo, São Paulo, 2002.

GEERTZ, C. A interpretação das culturas. Rio de Janeiro: LTC, 2008.

GOLDMAN, M. Antropologia contemporânea, sociedades complexas e outras questões. Anuário Antropológico/93. Rio de Janeiro: Tempo Brasileiro, 1995. 
GONÇALVES, A. Sobre o conceito de cultura na antropologia. Cadernos de Estudos Sociais, Recife, v. 25, n. 1, p. 61-74, 2010. Disponível em: https://periodicos.fundaj.gov.br/CAD/article/view/1416. Acesso em: 11 nov. 2020.

KUPER, A. The invention of primitive society, London, New York: Routledge, 1988.

LAS CASAS, Bartolome de. A short account of the destruction of the indies. London: Penguin Books Limited, 1992.

LECRERC, Gerard. Crítica da antropologia. Lisboa: Praxis22, Martins Fontes, 1973.

LÉVI-STRAUSS, Claude. Raça e história, In: LÉVI-STRAUSS, Claude. Antropologia estrutural dois. 3. ed. Rio de Janeiro: Tempo Brasileiro, 1989. p. 328-366.

LOWIE. Robert. Primitive society. EUA: Black and Golden Edition. 1947

MALINOWSKI, B. Os argonautas do Pacífico Ocidental. São Paulo: Abril Cultural, 1978. Coleção os Pensadores.

MAUSS, M. Ensaio sobre a dádiva: forma e razão da troca nas sociedades arcaicas. São Paulo: Edusp,1974.

MERCIER, Paul. História da antropologia. Lisboa: Teorema, 1986.

OLIVEIRA, Roberto de. Sobre o pensamento antropológico. Rio de Janeiro: Tempo Brasileiro, 1988.

SPENCER, Herbert. Progress: its law and cause. Herbert Spencer Collected Writtings, V. X. Londres: Routledge \& Thoemmes Press, 1996.

STOCKING JR, George. (org.). Franz Boas: a formação da antropologia americana. 1883-1911. Rio de Janeiro: Editora UFRJ, 2004.

STOCKING JR, George. Colonial Situations: essays on the contextualization of ethnographic knowledge. University of Wisconsin Press: Editor George Stocking JR, 1993. V. 7, (History of Anthropology).

STOCKING JR, George. Victorian Anthropology. Oxford: Oxford University Press, 1987.

TYLOR, E. La ciencia de la cultura. In: KAHN J.S. El concepto de cultura: textos fundamentales. Barcelona: Anagrama, 1975, p. 29-46.

Recebido em: 27/04/20.

Aceito em: 27/08/20. 